Vol. 2, No. 03; 2019

ISSN: 2581-4664

\title{
FORENSIC ACCOUNTING POLICIES AND FRAUD CONTROL IN COUNTY GOVERNMENTS IN KENYA: EVIDENCE FROM COUNTIES IN MT.KENYA REGION
}

\author{
Jephitha Kirimi Karuti ,Dr. Gillian Mwaniki and Prof. George King'oriah \\ Kenya Methodist University
}

http://doi.org/10.35409/IJBMER.2019.2438

\begin{abstract}
In the current century, fraud has become an issue that management and other stakeholders are aggressively trying to bring to a sustainable level. Fraud instances have been increasing in many organisations amidst continuous fight by governments and other agencies. The purpose of the study was to establish how forensic accounting policies would influence fraud control in County Government in Kenya. Seven counties in the Mount Kenya region were considered as the target population as well as the study sample size constituting of 351 staff members. To establish the level of statistical significance between the practical and predictable value, Analysis of variance (ANOVA) was used. Pearson coefficient of correlation was used to establish the strength of association among the variables while Regression analysis was used to approximate the model coefficients. Moreover, test of hypothesis was also carried out to define the relationship between the variables. In General, the study concluded that there was a positive linear relationship between Forensic Accounting policies and fraud control. It was evident that forensic accounting policies influenced fraud control by a coefficient of (0.219). The study therefore concluded that adoption of forensic accounting policies in county governments in Kenya would enormously contribute to fraud control in the public entities.
\end{abstract}

Keyword: Forensic accounting, Fraud, Fraud control and Forensic accounting policies.

\section{INTRODUCTION}

\subsection{Background to the Study}

The primary objective of fraud control is to determine hidden patterns of deceitful activities in order to uncover them and come up with salvage tactics to alleviate possible losses. Fraud is a complicated occurrence which requires an in-depth understanding in order to comprehend its peculiar behaviour when designing fraud control devices. The commonly used fraud control techniques in many organisations have been deficient of clear cut policies which can substantially govern fraud control (Baesens, Vlasselaer, \& Verbeke, 2015). Fundamentally, fraud control needs a sophisticated policy approach which should be tailored towards forensic examination (Baesens, Vlasselaer, \& Verbeke, 2015). The contemporary fraud control techniques are deficient of adequate policies because they are normally anchored on labour- 


\section{International Journal of Business Management and Economic Review}

Vol. 2, No. 03; 2019

ISSN: 2581-4664

intensive investigation which heavily relies on human ability, which is tremendously a costly undertaking. Forensic accounting policies help to reasonably comprehend fraud control technique which can recognise signs of fraudulent behaviour and support adequate examination of organisation's financial reports (Savona \& Berlusconi, 2015). Noviyanti \& Winata (2015) reputed that a refined forensic accounting policy stand by 5/10/85 canon, which supports that $5 \%$ of employees can steal regardless of the conditions, $10 \%$ may not steal, and $85 \%$ may act fraudulently, depending on the underlying circumstance in the institution. COSOTC (2010) claimed that Fraud in an organization can be committed either internally by employees, managers, officers, or owners of the company, or externally by customers, vendors and other parties. Klynveld Peat Marwick Goeldeler (KPMG) Malaysia (2013) revealed that employees were the highest perpetrators of fraud represented by about $50 \%$ particularly those who were not in the management. Theft of outgoing funds has been found to be at about $67 \%$, theft of tangible assets at 58\%, misappropriation of incoming funds at 34\%, theft of cash and cash receipts at $26 \%$, false invoicing $16 \%$ and loss of inventory at 13\%. Ernst \& Young (2014) agree that Governments and corporations across the globe have been claimed by fraud, bribery and corruption which requires decisive steps to reduce them if the world economy has to grow immensely .

Although there have been increased awareness on fraud and how it can be perpetrated the rise in financial scandals in the Twenty First Century have occurred under the watch of auditors which has put them on a questionable position in relation to fraud prevention and detection (World Bank, 2016). The rate of occurrence of financial fraud has not shown any decline since Sarbanes Oxley Act was passed in 2002 to reinforce corporate responsive behavior and strengthen disclosure mechanism which depicts lack of adequate policies (Hogan Rezaee, Riley \& Velury, 2008). The emergence of fraud in organizations has made traditional approach of auditing unreliable in detection and prevention of various types of fraud. Fraud has been construed as a problem universal to many countries and no nations is immune to it with developing countries suffering the most stress. Therefore, the need to respond to organized fraud calls for the skills of accountant with non-ancient methods which has prompted the paradigm shift in accounting professional to forensic accounting (Feiya \& Otalor, 2013).

In Kenya fraud has been one of major contributors to slow growth in public and private sectors. Several management teams of the key corporations have been accused of poor corporate governance which has resulted to major corporate scandals which could have been deterred if there was proper use of forensic accounting policy. Some practical examples in Kenya includes collapse of Euro Bank in 2004, National Bank of Kenya, placement of Uchumi under receivership in 2004 and the near collapse of Unga group and board room wrangles on discovery of secret oversees bank accounts by directors of Computer Management Corporation (CMC) motors which eventually resulted to it selling to Alfatum (Iraya, Mwangi \& Muchoki, 2015). Recently imperial Banks and Chase Bank have been placed under receivership. According to Maina \& Sakwa (2012) many organizations in Kenya have been implicated with massive fraud which has resulted to the collapse of corporations such as Bulk Medicated Ltd and Nyaga Stock brokers where some of their financial statements implied that they were sound despite their internal weakness. Donors have been reluctant to give aid to Kenyan government due to fraud amidst measures which have been put to combat crime like Ethics and Anti-corruption Commission (EACC), Intergrated Finance Management Information System (IFMIS), Director 


\section{International Journal of Business Management and Economic Review}

Vol. 2, No. 03; 2019

ISSN: 2581-4664

of Public Prosecution (DPP) and Director of Criminal Investigation (DCI) (UN-REDS program, 2013). Fraud being a product of change in accounting needs has enormously resulted to dishonesty in the society and therefore proper accounting policies need to be developed day by day. In Kenya fraud has led to slow economic growth and over reliance in debts notwithstanding many resolutions and regulations by Central bank of Kenya (CBK, 2014 ; BFID Annual Report, 2015). Oguda, Odhiambo \& Byaruhanga (2015) investigated the effects of components of internal control on fraud detection and prevention among the district treasuries of Kakamega County and established that fraud detection attacks the root causes and enablers of fraud. They recommended that improving organizational procedures to reduce or eliminate the causal factors of fraud was the single best defence against fraud. Their study was slightly similar to the current study only that it was extending further to investigate other component that may influence fraud control in a different region. With emergence of these empirical evidence across the globe necessited the exploration of the study's research problem to act as an eye opener to Kenyan County Governments on the importance of forensic accounting policy in control of fraud.

\subsection{Statement to the Problem}

Fraudulent actions are on the rise and have been considered as the major threats to the global economy (Popoola, Ahmad \& Samsudin, 2014). Therefore, fraud disclosure policies must continue to advance to a practical level if the world has live its dream of fraud control (Gill, 2009). Internal fraud typologies and fraud loss has been rising up with less recovery rate because fraudsters are becoming more classic in the use of technology and in their capability to commit and cover deceitful activities (CBK, 2014 ; BFID Annual Report, 2015). Many countries in developing countries have been rated as trailblazer's in occupation fraud at $66 \%$ which is alleged to be twofold the worldwide average which stands at 34\% in the public sector (Mahinda, 2012).

EACC Annual Report 2015/2016, revealed that complaints and allegations under investigation were found to be $24 \%$ on embezzlement of public funds, $10 \%$ public procurement irregularities and $6 \%$ fraudulent on acquisition and disposal of public property. The number of completed investigated cases in the EACC Annual Report 2015/2016 were 78 out of which 34 belonged to Executive and County Assemblies of various County Governments in Kenya. Out of 101 cases under active forensic investigation 48 of them were on various county governments in Kenya. Compared to other institutions in Kenya the trend seem to be alarming and would go out of hand and therefore forensic accounting policies has become a necessity in curtailing uncontrollable fraud and corruption in the county Governments in Kenya. Despite the government spending on training public accountants in the area of forensic accounting, many county goverments have not developed adequate policies which can hands-on seal loopholes on income pilferage. Therefore this study sought to establish how application of forensic accounting policies would help in fraud control in the county governments in Kenya.

\subsection{The purpose of the study.}

The objectives of these study was to determine the influence of forensic accounting policies on fraud control among the county governments in Kenya. 


\section{International Journal of Business Management and Economic Review}

Vol. 2, No. 03; 2019

ISSN: 2581-4664

\subsection{Hypothesis}

This study strived to respond to the following hypothesis:

Ho1: Existence of forensic accounting policies had no significant influence on the fraud control in county governments.

\section{LITERATURE REVIEW}

\subsection{Theoretical Framework}

\section{Deterrence Theory}

Deterrence theory has its origin in the writings of the 18th century philosophers Jeremy Bentham (1948) and Beccaria Cesare (1963) who pointed out that human beings were self-interested and rational-thinking, driven in their actions by an economical 'hedonistic calculus' whereby they act so as to maximize pleasure and minimize pain ( Paternoster, 2010; Tombs \& Whyte, 2013). This theoretically opens a Pandora's Box to 'deterrence' whereby as much as raising the costs of a behavior through sanctions to lower the willingness to pursue bad course of action fraud is still an enemy to the public service. According to this theory individual's fear of punishment has a negative impact on the intention to commit fraud (Nagin \& Pogarsky, 2001). Deterrence is helpful in public entities in order to control employees' behaviour especially in the fight against fraud. Deterrence is considered to be the best method to counter fraud. Therefore,there is a dire need to develop strategies that can prevent individuals from acting fraudulently. It is crystal clear that prevention is better than cure and engagement of forensic accountant is the only remedy in fraud control (Nagin \& Pogarsky, 2001).

As the governments across the globe realize the importance of counteracting employee's fraudulent actions and the possible risks they might cause, deterrence theory has been key and forensic accountants could play a great role in deterrement of fraud (D'Arcy \& Herath, 2011). D'Arcy \& Herath (2011) established that detection and punishment of perpetrators of fraud lowered the amount of fraud such as raising awareness and provision of clear information on repercussions in case one is a culprit. According to this theory, the more stringent the punishment and stronger the sanctions, the more excellent employees behave which is the key remedy in fraud control (Herath \& Rao, 2009). Deterrence techniques makes people to estimates the possibility of getting caught and the consequence of their actions before making decision on whether to break the rules or not (D'Arcy, Hovav \& Galletta, 2009). One of the biggest problems in proving whether deterrence methods have been beneficial on fraud control is that the results are very hard to evaluate and monitor (Herath \& Rao 2009). Monitoring employees can be very costly and complicated even if there is engagement of forensic accountants. For example, continuous check by forensic accountants might instil fear on the employees especially if they know that their actions are being surveilled mainly due to complexity and profound differences in their organizations and the methods of control put in place (D'Arcy et al. 2009). Regardless of the problematics in monitoring the results, deterrence theory is widely used in organizations to prevent and detect fraud (Herath \& Rao, 2009). All in all, deterrence is still considered to be the strongest theory in fraud control. 


\section{International Journal of Business Management and Economic Review}

Vol. 2, No. 03; 2019

ISSN: 2581-4664

In the current study, deterrence theory has been used to predict employee' behaviors in different circumstances because behavior is either supportive or disruptive of fraud control (D'Arcy \& Herath, 2011). The reason is that fraud is a result of employees failure to adhere to the financial control policies by using their designations for personal gain (Herath \& Rao, 2009). Therefore, deterrence theory is one of the most-used theories on fraud management policy (Siponen \& Vance 2010, D’Arcy \& Herath 2011).Fraud deterrence theory was useful in the present study because fraud is not a random occurrence; fraud occurs where the conditions are right for it to occur. Fraud deterrence outbreaks the root causes and enablers of fraud. It was important to establish potential fraud opportunities and how incorporation of forensic accounting policies could eliminate the causal factors of fraud as the single best defense against fraud. Although fraud deterrence involve both short-term and long-term initiatives it may not be fraud detection, which has often been the confusing point. Fraud detection involves a appraisal of ancient transactions to identify signs of a non-conforming transaction. Deterrence involves an analysis of the circumstances and behaviors that enable fraud by looking at what could happen in the future on a given process and what measures could be put in place such as engagement of forensic accounting policies.

\subsection{Empirical review}

\subsubsection{Forensic Accounting policies and Fraud Control}

Many organizations are on the verge of unclear accounting policies. Forensic accounting policies and procedures are steps which organisations can use to manage their internal controls to prevent and detect fraud. Organisations needs to develop and implement proper policies in order to achieve organizational goals and decrease the risk of fraud of whatever nature. Guo, Huang, Zhang \& Zhou (2016)) suggested that organizations with better and employee-friendly forensic accounting policies are less likely to have ineffective internal controls because the workers will be more motivated to ensure that the organisation succeds regardless of the situation.

Verovska (2014) enunciated that the purpose of proper forensic accounting policies is to improve organisation's financial strength and create a competitive edge in order to maximize shareholder's wealth. Ngwenya \& Munyanyi (2015) defined forensic accounting policies as the procedures and policies that are made and executed to enhance efficiency, inspire accuracy in accounting and non-accounting procedures by upholding laid down laws and regulations. On the other hand, Dowling (2014) defined policies as instruments developed to inspire personnel to attain desired goals in the organisation. Due to fraud many public and private organisations have run away from their business decisions and organisations policies making financial reporting to change in a great deal. One of the particular requirements which deterred and prevented fraud was ensuring that financial report did not contain any untrue statements of a material fact or omission of a material fact which could make financial statements misleading (Kranacher, 2011). One of the fundamental policy to prevent fraud was SOX section 304 which opined that an organization was required to restate its financial statements on account of misconduct, the chief executive officer was responsible for compensating the company (Amadeo, 2017). One key regulation borrowed from the Sarbanes Oxley Act by the county governments was the operating of the audit committee which is one of the most essential elements of internal control over financial reporting (Gramling \& Hermanson, 2009). The gazette notice of April 16, 2016 mandated that all the county governments need to establish audit committees for which only a 


\section{International Journal of Business Management and Economic Review}

Vol. 2, No. 03; 2019

ISSN: 2581-4664

few are in the process of formation. Section 301 of the Sarbanes Act contains six components with different requirements for audit committee which in the county government is a mere dream (SOX, 2002). Following a high profile cases across the globe such as Enron, SOX was a crucial piece of legislation meant to reinforce corporate responsive behavior, strengthen disclosure mechanism and fight against fraud (Hoyle, Schaefer \& Douphik, 2011). According to (Gramling et., al., 2009), since the execution of SOX, audit committee effectiveness has improved but the contrast is still in county governments. The audit committee being outside the scope of management can remain unbiased in every aspect and thus help in deter occurrence of fraud (Akenbor \& Oghoghomeh, 2013).

Corporate responsive behavior and good working environments enhances employees compliance to established rules, policies and procedures which are set for the success and sustainability of the business or the organisation. A good working environment enhances communication between employees and management and guarantees positive employee recognition and great reward system. This kind of working atmosphere reduces the levels of internal fraud in the organization but county politics has thrown this on the back sit (Kingsley, 2012). Organisations needs to enforce a workforce culture with adequate and sufficient policies, rules, regulations, procedures and protocols to deter fraudulent and corrupt behaviors that deal swiftly with incidents and protect whistle blowers (ACFE, 2009). County goverments have a duty to understand their customer especially the suppliers in order to identify all the traits of fraud which might emanate out of collusion with the management alongside updating existing files and monitoring their operations in order to detect fraud (Hardouin, 2009). Daily monitoring of transactions should also be carried out in order to spot unusual transactions (Prabowo, 2012). According the ACFE (2016), review of bank accounts, expense reimbursements and petty cash control policies are essential in detection of fraud schemes. In addition, Negurita \& Ionescu (2016) recommended that management should adequately supervise employees who are responsible for assets, particularly those assets which the top management cannot easily identify and can be easily converted ito cash . Further, Kapp \& Heslop (2015) suggested key source documents should be pre-numbered chronologically and reviewed to ensure that none has been removed or cancelled. Management should ensure that accounting and books of prime entry have been linked together which should be properly documented in the finance policies and procedures.

Every government entity should not assume that all employees know what is expected of them. A code of conduct, which includes an explanation of the organization's values that are based on honesty and integrity, should be included in the employee manual as a separate document as well as emphasized in employee training seminars and recruitment process. McNeal (2016) highlighted that it is important for employees instruction manual to include the organization's mission statement and its core values in order to incalcate organisation policies and practices. Henry (2016) stressed that a written code of conduct policy equips employees with the knowledge of the ethical values of the organization, the skills necessary to detect fraud, and the training on the actions which need to be taken when fraud is alleged. Nevertheless, amidist enactment of proper code of conduct which enables the entity to act honestly and in unity the bottom line is identification of the possible ways in which fraud can occur in order to mitigate the risk (Biegelman \& Bartow 2006). Organisation's policies, procedures and methods needs to be made known to all the employees for a deceitful act to be called fraud since wrongdoers could defend themselves by justifying that fraud has occurred by mistake (Kovavich, 2008). 


\section{International Journal of Business Management and Economic Review}

Vol. 2, No. 03; 2019

ISSN: 2581-4664

Engagement of compliance officers such a forensic accountants in government institutions such a county government to be in charge of compliance training and compliance committee would greatly help employees conform to the pertinent policies and procedures (Biegelman \& Bartow 2006).

On the other hand, policies and regulations on approvals, endorsements, reconciliations, authentications and separation of responsibilities must be prearranged well and be stringently adhered to by the workers because they build the entities internal control base to reduce fraud risk (Rae \& Subramaniam, 2017). The departmental communication needs to be enhanced both horizontally, vertically and laterally because different people perceive forensic accountants differently and performance evaluation and rewarding may be curtailed. Organisation's standards of controls needs to be excellent with clear separation of duties, to avoid confusion by inexperienced accountants who might fail to unearth a problem and therefore forensic accountants can be the only remedy. Individual code of ethics should be created by the organization (Biegelman \& Bartow 2012). Organisations code of conduct acts as a "moral compass" for the employees by promoting ethical issues and integrity. Governments should be on the front in maintaing ethical culture by defining principles and values which has indicators of high levels of ethics as well as zero tolerance to corruption and fraud (ACFE, 2009). Ethical principles enhances organisation's climate by shaping employees mindset in prevention and detection of fraud. Ethical culture is usually incorporated through right leadership as a model for indoctrinating proper behavior that would deter employees from engaging in fraud (ACFE, 2009).

According to Giorgini et al. (2015) codes of ethics are moral and professional guidelines for ethical behaviour's. Ethics policy helps employees to act ethically, endorses a vigorous public appearance, and maintain the tone of higher ethical standards. It is through proper code of conduct that employees are made aware of dangers and consequences of unethical behaviour. It is a wise thing for county governments to ensure there exist a proper code of ethics which acts as an ethical guide to be followed on day to day basis in the work environment. Conversely, codes of conduct cannot be used single-handedly to measure fraudulent activities and prevent fraud but it is an important component in fraud control (Bromley \& Orchard, 2016). Codes of conduct policies are key instruments on enhancement of transparent culture and a key requisite in fraud prevention through development of formal idea on the expected behaviour's (Andrade, Hamza \& Duarte,2017). Chiu, Huang, Lin, \& Yen (2015) noted that ethics policy help in indoctrinating organization's mission and vision by enhancing due diligence. Ethically enriched culture thwarts undesirable influences that lead to fraud such as pressure to commit fraud to meet certain financial goals (Morales et al., 2014).

Whistle blowing policy is a key step to fraud control in any organization across the globe. Although many organizations fear that inclusion of a whistle blower policy would results to negative public relations and retaliatory attacks from the fraudsters it is a great tool in fraud control (Young, 2014). Whistleblowing policy was created after accounting scandals in 2001 to aid employees in reporting suspected fraud incidences in a quicker manner in order to report illegitimate, wicked and illegal practices in an organization (Gao \& Brink, 2017). In addition, whistle-blower hotline is a key instrument to fraud prevention because it allows employees or individuals to report suspected fraud to enhance culprits restitution (Redman \& Caplan, 2015; Morales et al. 2014). Nevertheless, not everybody can recognize fraudulent activity and as such 


\section{International Journal of Business Management and Economic Review}

Vol. 2, No. 03; 2019

ISSN: 2581-4664

employees need to be trained on fraud control with much education on the consequences of nonreporting of suspected fraud cases. It is clear that whistle-blower policy and conflict of interest policy on top of strong due diligence are key tenets on fraud control (Lee, 2016). The policies on accountability and good governance are essential components on fraud control.

In conclusion as elucidated by ACFE (2016) every organization needs a policy on fraud prevention check-up test which is important in discovering the organization's level of fraud risk. Bailey (2016) endorsed that fraud prevention and deterence policies should be written and well documented and indoctrinated to all employees to ensure that they do not act under conflict of interest. Every County government has a duty to develop an approach of dealing with fraud which should be clearly stated in the fraud policy. The policies established should facilitate execution and actualization of internal controls and should assist in detection and prevention of fraud (ACFE, 2009). A fraud policy should include the scope, what actions constitute a fraud, the unit responsible for investigations, confidentiality clauses, and an authorization for investigating suspected fraud, reporting procedures, and termination procedures.

Fig 2.1: Conceptual Framework

Independent variables

Intervening variable

Dependent variable

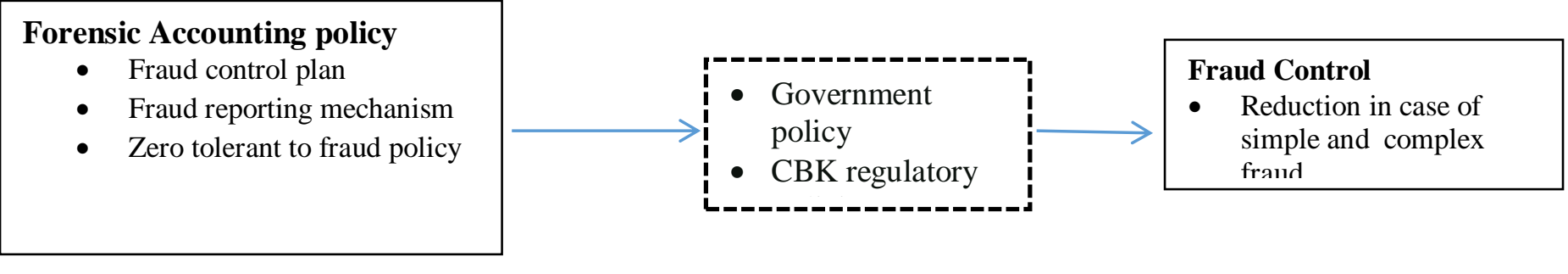

\section{METHODOLOGY}

\subsection{Research Philosophy}

The study embraced positivist research philosophy because is based on knowledge gained from positive verification of observable experience rather than introspection or intuition (Mwaniki, 2015; Levin , 2013).

\subsection{Research Design}

Descriptive research design using survey method was adopted. The design was embraced because it detailed described the nature of forensic accounting policies and their contribution to fraud control by examining activities as they occur rather than variable manipulation (Mitchell \& Jolley, 2010).

\subsection{Target population}

The target population for this study was 351 staff of 7 County Governments in Mount Kenya region entailing of Auditors, Accountants,Revenue officers and the Chief Officers.

\subsection{Sampling Procedure and Sample Size.}

The study considered individual counties selected as an echelon and used census technique to 


\section{International Journal of Business Management and Economic Review}

Vol. 2, No. 03; 2019

ISSN: 2581-4664

include all the subjects from each county in the study. Census technique was adopted because it was imperative to purposively include all the members in each county. Therefore, the sample size for the study was 351 respondents.

\subsection{Research Instruments}

The study banked on on primary data with the questionnaires as the main tools because the study was concerned with variables that could not be openly experimental such as sentiments, feelings, insights and sensations of the respondents (Touliatos \& Compton, 2013). A questionnaire for the county staff was created to capture relevant information on the objectives of the study. The questionnaire had both open and closed questions with each item capturing specific relevant data to avoid vagueness of the data collected. Since the study was considered to be opinion based, responses at a five Likert scale was used. To ensure the data provided was rich and more inclusive interview schedules were prepared to triangularise the data obtained.

\subsection{Reliability and Validity of Data Collection Instruments}

The reliability of the instruments was done to check the stability or consistency of scores over time. Two sets of data for each tool were used to compute the Pearson Moment Correlation Coefficients. Korb (2016), adviced that if the calculated consistency index for a tool was greater than 0.6 then the tool was consistent. The questionnaire had reliability index greater than 0.6 and therefore was considered dependable for the study.

To boost validity of the tools test, retest method was used. Auxiliary validation of the tool was done to ensure that all the items in each instrument were based on the study objectives. Two sets of data from each instrument were used to work out the content validity index for the instrument. Validity was determined by giving two experts to evaluate the relevance of each item in the instrument to the objectives and rate each item on the scale of very relevant (4), quite relevant (3), somewhat relevant (2) and not relevant (1). Validity was determined using content validity index (C.V.I), C.V.I= items rated 3 or 4 by both judges divided by the total number of items in the questionnaire. This was symbolized as $\mathrm{n}^{3} / 4 / \mathrm{N}$. The CVI computed for each tool was greater than 0.6 hence the instrument was considered valid as advised by Jeffry, (2011).

\subsection{Data Analysis and Presentation}

Data analysis was done using statistical package for social science, (SPSS) version 20.0. Analysis of the data was done mainly by use of frequencies, percentages, regression and correlation. The outcomes of the study were presented in form of tables. The study used a multiple regression analysis to show the influence and effect of the independent variable on the dependent variable. In relation to inferential statistics the study used analysis of variance and multivariate regression analysis to test the hypotheses of the study.

\section{KEY FINDINGS/RESULTS}

\subsection{Findings on Forensic Accounting policies and Fraud Control.}

The study analysed the extent to which forensic accounting policies influenced fraud control in County Governments in Kenya. The quantitative analyses result revealed that forensic accounting policies influenced fraud control.

Table 4.1 Forensic accounting policies and Fraud control 
International Journal of Business Management and Economic Review

Vol. 2, No. 03; 2019

ISSN: 2581-4664

Table 4.1: Model Summary for Forensic accounting policies and Fraud control

\begin{tabular}{|clcc|}
\hline R & R Square & Adjusted R Square & $\begin{array}{l}\text { Std. Error of the } \\
\text { Estimate }\end{array}$
\end{tabular}

The results in table 4.1 revealed that, the R-squared for the relationship between forensic accounting policies $\left(\mathrm{X}_{1}\right)$ and fraud control was .306 . This indicated that forensic accounting policies could explain $30.6 \%$ of the dependent variable (fraud control) variation. It explained that $30.6 \%$ of the variation in the fraud control could be explained by a unit change in forensic accounting policies, while the remaining $69.4 \%$ could be explained by other variables. These insinuates that forensic accounting policies play a significant role in enhancing fraud control. The findings were supported by Lee (2016) who suggested that policies on accountability and good corporate governance on top of strong due diligence were essential components for fraud control.

ANOVA for Forensic accounting policies and Fraud control

The study used ANOVA to establish the significance of the regression model. In testing the significance level, the statistical significance was considered if the p-value was less or equal to 0.05 .

Table 4.32:ANOVA for Forensic Accounting policies and Fraud control

\begin{tabular}{|llllll|}
\hline & Sum of Squares & Df & Mean Square & F & Sig. \\
\hline Regression & 5.773 & 1 & 5.773 & 50.617 & .000 \\
Residual & 13.117 & 275 & .114 & & \\
Total & 18.890 & 276 & & & \\
\hline
\end{tabular}

Source; Survey Data (2019)

The significance of the regression model was shown in the Table 4.2 with P-value of 0.00 which was less than 0.05 . This indicated that the regression model was statistically significant in predicting the effect of forensic accounting policies on fraud control in Kenya. The ANOVA results shown in table 4.2 depict that; the F-critical $(1,275)$ was 3.88 while the F-calculated was 50.617. This demonstrated that the F-calculated was greater than the F-critical hence there was a linear relationship between the two variables (forensic accounting policies and fraud control). This implied that when there was an increased usage of forensic accounting policies fraud control was a significant. This thus confirmed goodness of fit of the model in predicting the influence of forensic accounting policies $\left(\mathrm{X}_{1}\right)$ on fraud control. The result were consistent with the studies by Brink \& Gao (2017) who confirmed that forensic accounting policies such as whistleblowing policy assist employees in reporting suspected fraud incidences in a quicker manner in order to report illegitimate, wicked and illegal practices in an organization.

Regression Coefficients for Forensic accounting policies and Fraud control

Using the unstandardized coefficients the following equation applied:

$\mathrm{Y}=2.544+0.357 \mathrm{X}_{1}$

Table 4.3: Regression Coefficients for Forensic accounting policies and Fraud control

\begin{tabular}{llll}
$\begin{array}{l}\text { Unstandardized } \\
\text { Coefficients }\end{array}$ & $\begin{array}{l}\text { Standardized } \\
\text { Coefficient }\end{array}$ & t & Sig. \\
\hline
\end{tabular}


International Journal of Business Management and Economic Review

Vol. 2, No. 03; 2019

ISSN: 2581-4664

\begin{tabular}{|c|c|c|c|c|c|}
\hline & B & Std. Error & Beta & & \\
\hline (Constant) & 2.544 & .227 & & 11.201 & .000 \\
\hline $\begin{array}{l}\text { Forensic management } \\
\text { policies }\end{array}$ & .357 & .050 & .553 & 7.115 & .000 \\
\hline
\end{tabular}

\section{Source; Survey Data (2019)}

The results in table 4.3 indicated that fraud control had an index of 2.544 when forensic accounting policies $\left(\mathrm{X}_{1}\right)$ were held constant. In addition, the Beta coefficient $\left(\beta_{4}\right)$ was 0.357 . This revealed that a unit increase in forensic accounting policies $\left(\mathrm{X}_{4}\right)$ would result to $39.7 \%$ influence in fraud control. In addition, the t calculated (7.115) was greater than the t critical (1.645) hence the relationship was significant as the P-value (0.000) was less than the significance level (0.05).

\subsection{Summary of Hypothesis Testing Results}

The results of hypothesis test show that the hypothesized relationship was statistically significant meaning they forensic accounting policies contributed immensely to fraud control.

\section{$H_{a} 1$ : There was a positive significant relationship between forensic accounting policies and fraud control in the county government in Kenya.}

The results in the Table 4.3 indicated that he Beta coefficient $\left(\beta_{4}\right)$ was 0.357 . The relationship was significant as the P-value (0.000) was less than the significance level (0.05), and the $t$ calculated (7.115) was greater than the $t$ critical (1.645). The alternative hypothesis was accepted and it was therefore concluded that, "there was a positive significant relationship between forensic accounting policies and fraud control in the county government in Kenya". These findings concurred with assertions by Guo, Huang, Zhang \& Zhou (2016)) who suggested that organizations with better and employee-friendly forensic accounting policies would result to effective internal controls because the workers would be motivated to ensure that the organisation succeds in whatever nature. Similarly, the assertions confirmed the work of Verovska (2014) who enunciated that proper forensic accounting policies improved organisation's financial strength and maximized shareholder's wealth through reduction of risks such as fraud.

\section{CONCLUSIONS}

The rationalization for the study of this nature could not be undermined as fraud remains a deep wound on the devolved units of our country. The degree at which fraud is extending its roots in the County government and the perceived desperation by the citizens had got the attention of the researcher which was the key driver for carrying this research. The research heavily relied on quantitative data with supplement of qualitative data to examine the contribution of forensic accounting policies on fraud control in county governments in Kenya. The study identified the influence of forensic accounting policies on fraud control in county governments.It was notable that the relationship between the two constructs was not as strong as expected although it was positive. The researcher attributes this to the fact that devolved units in Kenya were still at the formative stages with policies not clearly established and a lot of duplication from the National government.

The findings of the study show that forensic accounting policies were not perceived by the county government employees to be the most effective tools in fighting the threat of fraud. The study established that there were a number of policies to combat fraud such as use of fraud 


\section{International Journal of Business Management and Economic Review}

Vol. 2, No. 03; 2019

ISSN: 2581-4664

control plan, zero tolerance to fraud and corruption, efficient fraud reporting mechanism and policy on checking and updating of inventory. Out of the four, only the policy on checking and updating of inventory was properly adhered to with others merely appearing on papers on county government sign boards and policy manuals. It was established that many county governments had no policy on effective fraud reporting and fraud control plan was a mere rhetoric from County Government employees.

\subsection{Recommendations}

With respect to the findings of this study and in the spirit of curtailing fraud in county goverment and other government entities, it is recommended that organisations should enhance forensic accounting policies in their quest to control fraud. Additionally, both the national and county government should provide a conducive environment for forensic accounting discipline to get its root in order to move with the global trend in fraud control. This was in view of the fact that county accountants and executives had enacted few policies on the application of forensic accounting in County Governments in Kenya.

Finally, all regulatory bodies, including the Institute of Certified Public Accountants (ICPAK) and the Institute of Internal Auditors (IIA) should include forensic accounting in the curriculum as well as its training to act as a key requirement to full membership accredition in their respective professions.

\section{REFERENCES}

ACFE (2009). Report to the Nation on occupation Fraud and Abuse.

Akenbor, C., O. \& Oghoghomeh, T. (2013). Forensic Auditing and Financial Crime Policies in Nigerian banks. A proactive approach, The Business \& Management Review, 4(2), 15 29. Retrived from http:// www.mpra.ub.unimuenchen.de/

Amadeo, K. (2017, July 18). 4 Ways the Sarbanes-Oxley Act of 2002 Stops Corporate Fraud. Retrieved February 09, 2018,

Association of Certified Fraud Examiners. (2016). Report to the nations on occupational fraud and abuse.

Baesens, Bart \& Van Vlasselaer, Véronique \& Verbeke, Wouter (2015). Fraud analytics using descriptive, predictive, and social network techniques. A guide to data science for fraud detection.

Beccaria, Cesare. 1963 [1764]. On Crimes and Punishment. New York, NY: Macmillan Publishing Company.

Bentham, Jeremy. (1948). An Introduction to the Principles of Morals and Legislation. New York, NY: Hafner Publishing Company.

BFID Annual Report (2015). Confidential Publication by Directorate of Criminal Investigation and Central Bank of Kenya.

Biegelman, M. T. \& Bartow, J. T. (2006). Executive Roadmap to Fraud Prevention and Internal Control. Creating a Culture of Compliance. 1st ed. USA: John Wiley \& Sons, Inc.

Biegelman, M. T., \& Barlow, J. T. (2012). Executive roadmap to fraud prevention and internal control: Creating a culture of compliance. Hoboken, NJ: John Wiley \& Sons, Inc. 


\section{International Journal of Business Management and Economic Review}

Vol. 2, No. 03; 2019

ISSN: 2581-4664

Bromley, P., \& Orchard, C. D. (2016). Managed morality: The rise of professional codes of conduct in the US nonprofit sector. Nonprofit and Voluntary Sector Quarterly.

CBK (2013). Prudential Guidelines. Published in January 2013. Accessed through www.cbk.or.ke.

Chiu, A., Huang, S., Lin, C., \& Yen, D. (2015). Detecting the financial statement fraud: The analysis of the differences between data mining techniques and experts' judgments. Knowledge-Based Systems.

D'Arcy, J., Hovav, A. \& Galletta, D. (2009). User Awareness of Security Countermeasures and Its Impact on Information Systems Misuse: A Deterrence Approach. Information Systems Research, Articles in advance, (pp. 1-20).

D'Arcy, John \& Herath, Tejaswini. (2011). A review and analysis of deterrence theory in the IS security literature. Making sense of the disparate findings. EJIS. 20. 643-658. 10.1057/ejis.2011.23.

Dowling, G. R. (2014). The curious case of corporate tax avoidance: is it socially irresponsible? Journal of Business Ethics 124, 173-184. Doi: 10.1007/s10551-013-1862-4.

Feiya,O. \& Otalor, J.,I. (2013). Forensic Accounting as a Tool for Fighting Financial Crime in Nigeria. Research Journal of Finance and Accounting, 4(6),18-26.

Gao, Lei \& Brink, Alisa G., (2017). "Whistleblowing studies in accounting research: A review of experimental studies on the determinants of whistleblowing," Journal of Accounting Literature, Elsevier, vol.

Gill, W. (2009). Fighting Fraud with Advanced Analytics. Canadian Underwriter, Business Information Group, 76 (9), 28-32.

Giorgin p., Piras L., Paja E.,Cuel R., Porite D. \& Mylopouls (2016). Gamification solution for software acceptance: A comparative study of requirement engineering and organisation behaviour techniques. $11^{\text {th }}$ IEEE International Conference on Research challenge on Information Science.

Gramling, A., W. \& Hermanson, H. (2009). Audit committee material weaknesses in smaller reporting companies. The CPA Journal. 79(12): 24-29.Doi: 1925698771

Guo, J., Huang, P., Zhang, Y., \& Zhou, N. (2016). The effect of employee treatment policies on internal control weaknesses and financial restatements. The Accounting Review.

Guo, J., Huang, P., Zhang, Y., \& Zhou, N. (2016). The effect of employee treatment policies on internal control weaknesses and financial restatements. The Accounting Review.

Hardouin, P. (2009). Banks governance and public-private partnership in preventing and confronting organized crime, corruption and terrorism financing. Journal of Financial Crime.

Henry, L. (2016, April). Back to basics: Fraud prevention. Internal Auditor.

Herath, Tejaswini \& Raghav Rao, H. (2009). Protection motivation and deterrence: A framework for security policy compliance in organisations

Hogan, C.,E., Rezaee, Z., Riley, R.,A. \& Velury, U.K. (2008). Financial statement fraud: insights from the academic literature. Auditing: Journal of Practice and Theory. 27 (2): 231-252.

Hoyle, J., B., Schaefer, T., F., \& Doupnik, T., S. (2011). Advanced accounting (10th ed.).In Conference of Credit Scoring and Credit Control VII, Edinburgh, UK. 


\section{International Journal of Business Management and Economic Review}

Vol. 2, No. 03; 2019

ISSN: 2581-4664

Iraya C., Mwangi M. \& Muchoki G.W. (2015). "The Effect of Corporate Governance Practices on Earnings Management of Companies Listed at the Nairobi Securities Exchange." European Scientific Journal.

Jeffry, M., M. (2011). Content Validity and Estimation. Journal of Research Education 5(2):114127.Retrieved from Retrieved from https://www.research.acer.edu.au

Kapp, L., \& Heslop, G. (2015). A matter of life or death. Internal Auditor, 23-24. Retrieved from https://iaonline.theiia.org/2015/a-matter-of-life-and-death

Kingsley, A.( 2012). Frauds In Nigerian Banks : Nature, Deep-Seated Causes, Aftermaths And Probable Remedies, 3(May), 279-290.

Korb, J., K. (2016). A Guide to Appropriate Choose to Test Reliability Index of Research Tool using Three Approach. Journal of Sociology and Research, 43(7): 669 - 733

Kovacich, G. L. (2008). Fighting fraud: How to Establish and Manage an Anti-Fraud Program. Amsterdam: Butterworth-Heinemann.

KPMG Malaysia, (2013). KPMG Malaysia Fraud, Bribery and Corruption Survey

Kranacher, M. (2011). Full disclosure: All investors need to know. The CPA Journal, 81(4): 8096. Doi: 2324673101

Lee, Y. J. (2016). What encourages nonprofits' adoption of good governance policies? Nonprofit Management \& Leadership.

Levin, D. M. (2013). The opening of vision: Nihilism and the postmodern situation. London: Routledge.

Mahinda,C.G.(2012). Determinants of occupational fraud in commercial banks in Kenya.University of Nairobi.

Maina F.G \& Sakwa, M. M. (2012).Understanding financial distress among listed firms in Nairobi Securities Exchange: a quantitative approach using the z-score multidiscriminant financial analysis Model.

McNeal, A. (2016). What's your fraud IQ? This month: Employee handbooks and policies. Journal of Accountancy, 223(3), 38-42.

Mitchell, L. \& Jolley, J. (2010). Research Design Explained. 5th edition. London: Thompson Wadsworth.

Morales, J., Gendron, Y., \& Guenin-Paracini, H. (2014). The construction of the risky individual and vigilant organization, A genealogy of the fraud triangle. Accounting, Organizations and Society.

Mwaniki, B. M. (2015). Influence of Micro-Finance Institutions in Transforming Micro, Small and Medium Enterprises into Viable Businesses in Kenya. Unpublished PhD Thesis. JKUAT, Nairobi

Nagin, Daniel S. and Greg Pogarsky (2001). Integrating Celerity, Impulsivity, and Extralegal Sanction Threats into a Model of General Deterrence: Theory and Evidence. Criminology 39(4):865-890.

Negurita O., \& Ionescu, I. E. (2016). Risk factors for bank fraud arising as a consequence of misstatements resulting from misappropriation of assets. Economics, Management, and Financial Markets, 11(1), 330-337.

Ngwenya, B., \& Munyanyi, E. (2015). Assessment of the effectiveness of cash management 


\section{International Journal of Business Management and Economic Review}

Vol. 2, No. 03; 2019

ISSN: 2581-4664

internal controls in the Zimbabwe Red Cross Society chapter. International Journal of Research in Commerce \& Management, 6(3), 12-14.

Noviyanti, S., \& Winata, L. (2015). The role of "tone at the top" and knowledge of fraud on auditors' professional skeptical behavior. Contemporary Management Research.

Oguda, N., J., Odhiambo, A. \& Byaruhanga, J. (2015). Effect of Internal Control on Fraud Detection and Prevention in District Treasuries of Kakamega County. International Journal of Business and Management Invention, 4(1), 47 - 57. Retrieved from www.ijbmi.org.

Paternoster \& Raymond (2010). How Much Do We Really Know About Criminal Deterrence? Journal of Criminal Law and Criminology 100(3):765

Popoola, O. M. J. (2014). Forensic Accountants, Auditors, and Fraud: Capability and Competence Requirements in the Nigerian Public Sector. A thesis submitted to the Othman Yeop Abdullah Graduate School of Business, Universiti Utara Malaysia.

Popoola, O. M. J. (2014). Forensic Accountants, Auditors, and Fraud: Capability and Competence Requirements in the Nigerian Public Sector. A thesis submitted to the Othman Yeop Abdullah Graduate School of Business, Universiti Utara Malaysia.

Prabowo, H. Y. (2012). A better credit card prevention strategy for Indonesia. Journal of Money Laundering Control, 15 (3), 267-293.

Rae, K., Sands, J., \& Subramaniam, N. (2017). Associations among the five components within COSO Internal Control-Integrated Framework as the underpinning of quality corporate governance. Australian Accounting,

Sarbanes-Oxley Act of 2002. (2002). U.S. Securities and Exchange Commission

Savona, E.U., \& Berlusconi, G.(2015). Organized Crime Infiltration of Legitimate Businesses in Europe. A Pilot Project in Five European Countries

Siponen, Mikko \& Vance, A.O.. (2010). Neutralization: New Insights into the Problem of Employee Information Systems Security Policy Violations. MIS Quarterly: Management Information Systems.

Tombs, Steve \& David Whyte (2013). The Myths and Realities of Deterrence in Workplace Safety Regulation. British Journal of Criminology 53:746-763

Touliatos, J., \& Compton, N. H. (2013). Research methods in human ecology/home economics. Ames: Iowa State University Press.

UN-REDD PROGRAMME. (2013). A Corruption Risk Assesment for REDD+ in Kenya. Nairobi. Anti-Corruption Resource Center.

Verovska, L. (2014). Internal control system as continuous basis of efficient and stable company development. Regional Formation and Development Studies, 3(8), 240-246

World Bank Report (2016). Fraud Prevention and Internal Control in the 21st Century Era, carried out in 105 developing countries banking system, report WB144-105.

Young, N. (2014). How not-for-profits can reduce fraud risk. Journal of Accountancy. 